\title{
Measuring Agency Costs AND the Value of InVEstment OpPortunities of U. S. Bank Holding Companies With StOchastic Frontier Estimation*
}

\author{
JOSEPH P. HUGHES \\ RUTGERS UNIVERSITY \\ LORETTA J. MESTER \\ FEDERAL RESERVE BANK OF CLEVELAND \\ AND THE WHARTON SCHOOL, UNIVERSITY OF PENNSYLVANIA \\ CHOON-GEOL MOON \\ HANYANG UNIVERSITY
}

MAY 2016

Prepared for the Research Handbook on Competition in Banking and Finance, eds. Jacob A. Bikker and Laura Spierdijk, Edward Elgar Publishing.

\begin{abstract}
By eliminating the influence of statistical noise, stochastic frontier techniques permit the estimation of the best-practice value of a firm's investment opportunities and the magnitude of a firm's systematic failure to achieve its best-practice market value - a gauge of the magnitude of agency costs. These frontiers are estimated from the performance of all firms in the industry and, thus, capture best-practice performance that is, unlike Tobin's $q$ ratio, independent of the managerial decisions of any particular firm.

Using the frontier measure of performance applied to 2007 data on top-tier, publicly traded U. S. bank holding companies, we obtain evidence on market discipline: we find that higher managerial ownership at most banks tends to align the interests of insiders with those of outside owners and to be associated with improved financial performance; at most banks, higher blockholder ownership is associated with improved financial performance obtained from blockholders' monitoring; and, at most banks, higher product-market concentration is associated with poorer financial performance and the so-called managerial quiet life.

Using the frontier measure of investment opportunities, we find evidence that banks with relatively higher-valued investment opportunities achieve less of their potential market value, while banks with lowervalued opportunities achieve more of their potential value. In spite of their lower-valued opportunities, these banks, on average, achieve the same Tobin's $q$ ratio and, thus, appear better able to exploit their less valuable investment opportunities. Our results suggest that higher-valued opportunities may reduce managers' performance pressure and provide a stronger incentive to consume agency goods.
\end{abstract}

*The views expressed in this paper do not necessarily reflect those of the Federal Reserve Bank of Cleveland or the Federal Reserve System. Hughes thanks the Whitcomb Center for Research in Financial Services at the Rutgers Business School for its support of data services used in this research.

Correspondence to Hughes at Department of Economics, Rutgers University, New Brunswick, NJ 08901-1248; phone: (917) 721-0910; email: iphughes@,rci.rutgers.edu. To Mester at the Federal Reserve Bank of Cleveland, 1455 E. $6^{\text {th }}$ Street, Cleveland, OH 44114; email: Loretta.Mester@,clev.frb.org. To Moon at Department of Economics and Finance, College of Economics and Finance, Hanyang University, Seoul 133-791, Korea; phone: 82-2-2220-1035; email: mooncg@gmail.com.

JEL Codes: C58, G21, G28.

Key Words: banking, efficiency, ownership structure, competition 


\section{Measuring Agency Costs and the Value of InVestment Opportunities OF U. S. BANK Holding Companies With STOCHASTIC Frontier Estimation}

\section{Introduction}

The market value of a firm gauges the firm's expected financial performance, and, when the firm experiences agency problems, characteristics of the firm, such as its ownership structure and market concentration, are likely to be related to the firm's market value. Many studies have investigated the relationship between market value and ownership structure and between market value and market concentration. ${ }^{1}$ The statistical significance of these relationships suggests the presence but not the magnitude of agency problems. The magnitude of agency problems is given in part by the difference between a firm's highest potential value - its best-practice value - and the value it achieves, abstracting from statistical noise.

By eliminating the influence of statistical noise, stochastic frontier techniques permit the estimation of the best-practice value of a firm's investment opportunities and the magnitude of a firm's systematic failure to achieve its best-practice market value - a gauge of the magnitude of agency costs. The best-practice market value of a firm's investment in assets captures its potential value if it operated at least as efficiently as its industry peers - where peers are all firms of similar size. Thus, best practice captures not just technological performance, but also market positioning. If the observed market value of assets is plotted against the book value of the assets for all firms in the industry, an upper envelope (frontier) of market values that eliminates the influence of statistical noise would capture this notion of the best-practice value. And the difference between the frontier value and the achieved value, adjusted for statistical noise, would represent systematically lost market value - which we call market-value inefficiency. This market-value inefficiency is a gauge of the magnitude of agency costs, which would include things such as managerial incompetence,

\footnotetext{
${ }^{1}$ Core, Holthausen, and Larcker (1999) regress CEO compensation on three sets of variables: economic determinants of optimal compensation and variables characterizing ownership structure and board structure. They contend that, in the absence of agency problems, only variables related to economic determinants of optimal compensation should exhibit statistical significance. Instead, all three sets of variables show statistical significance and suggest that CEO compensation is higher at firms exhibiting characteristics of board and ownership structure associated with weaker governance. To provide further evidence on this link between characteristics of weak governance and compensation, they regress future financial performance on the proportion of current compensation explained by board and ownership structure, compensation not related to economic determinants of optimal compensation, and find a strong negative association.
} 
perquisite consumption, nepotism, taking too much or too little risk to protect managerial control, and so on. Because this frontier is estimated from the performance of all firms in the industry, it is independent of the managerial decisions of any particular firm. While Tobin's $q$ ratio characterizes achieved performance, the frontier provides a benchmark for measuring the shortfall of achieved performance from best practice.

If, in addition to controlling for size, the estimation of the upper envelope accounts for economic conditions in the particular markets in which the firm operates - for example, the long-term GDP growth rate and market concentration - the upper envelope gives the best-practice market value of the firm's assets where its peers are firms of similar size and market positioning. This best-practice value could be considered the value of the bank in a competitive auction, its charter value. We call the ratio of this measure of the value of the firm's investment opportunities to its book-value investment net of goodwill, the firm's investment opportunity ratio.

Note that these two frontiers differ in how they define a firm's peers for the purpose of estimating the highest potential value of its assets. The frontier that controls only for asset size defines peers as those firms of the same size in all markets in which the industry operates. Thus, market-value inefficiency defined by this frontier identifies market value from firms operating in the most valuable markets and penalizes firms operating in less valuable markets - just as capital markets penalize such market disadvantages. On the other hand, the frontier that controls for asset size and market conditions estimates the potential value of peers of similar size and with similar market opportunities. This potential value would generally be less than that obtained from the former frontier.

Using the frontier measure of performance estimated with 2007 data on top-tier, publicly traded U. S. bank holding companies, we obtain evidence on market discipline: we find that higher managerial ownership at most banks tends to align the interests of insiders with those of outside owners and to be associated with improved financial performance; at most banks, higher blockholder ownership is associated with improved financial performance obtained from blockholders' monitoring; and, at most banks, higher product-market concentration is associated with poorer financial performance and the so-called managerial quiet life, whereby 
managers engage in perquisite consumption and other inefficient behavior rather than maximizing firm value (see Hicks (1935), and also Berger and Hannan (1998) for an early application to banking).

Using the frontier measure of investment opportunities, we find evidence that banks with relatively higher-valued investment opportunities achieve less of their potential market value, while banks with lowervalued opportunities achieve more of their potential value. In spite of their lower-valued opportunities, these banks, on average, achieve the same Tobin's $q$ ratio and, thus, appear better able to exploit their less valuable investment opportunities. Our results suggest that higher-valued opportunities may reduce managers' performance pressure and provide a stronger incentive to consume agency goods.

We review the literature that uses this measure in Section I. In Section II we describe our application of this measure using 2007 data on top-tier, publicly traded U. S. bank holding companies to investigate the relationship of agency costs to ownership and market competition. We describe our technique for measuring the market-value shortfall and the value of investment opportunities more fully in Section III. In Section IV we compare these findings with those obtained from the commonly used Tobin's $q$ ratio and a calculation of the $q$ ratio obtained from the stochastic frontier estimation that eliminates statistical noise. Performance measured by the market-value shortfall gives much more precisely estimated evidence on these relationships than the commonly used Tobin's $q$ ratio. Section V provides conclusions.

\section{Literature Review}

A proxy for Tobin's $q$ ratio is frequently used to measure the performance of firms and to look for evidence of agency problems in firms' ownership structure. For example, Brook, Hendershott, and Lee (1998) control for performance with the $q$ ratio in a regression explaining the cumulative abnormal return obtained around the passage of the Interstate Banking and Branching Efficiency Act of 1994 and find that higher abnormal returns are associated with lower $q$ ratios except where managers exhibit evidence of entrenchment. McConnell and Servaes (1995) measure firm performance by the $q$ ratio in a regression considering the relationship of performance to capital structure. Yermack (1996) uses the $q$ ratio to investigate the relationship between firm performance and the size of the board of directors. While a 
relationship of Tobin's $q$ ratio with characteristics of these structures is frequently interpreted as evidence of agency problems, these relationships do not gauge the magnitude of agency costs.

Hughes, Lang, Moon, and Pagano (1997) proposed the market-value frontier and the shortfall measure of performance. Several studies have used either this measure of performance or the noise-adjusted Tobin's $q$ ratio derived from it: Habib and Ljungqvist (2005), Baele, DeJonghe, and Vander Vennet (2007), DeJonghe and Vander Vennet (2005), Hughes and Moon (2003), Hughes, Lang, Mester, and Moon (1999), Hughes, Mester, and Moon (2001), Hughes, Lang, Mester, Moon, and Pagano (2003), and Hughes and Mester (2013b).

Tobin's $q$ ratio is also used to measure the value of investment opportunities. For example, Yermack (2006) uses the $q$ ratio to measure and control for the value of investment opportunities in regressions explaining the personal use of company jets by the CEO, while Core, Holthausen, and Larcker (1999) use the market-to-book ratio to control for the value of investment opportunities in a regression explaining CEO compensation.

However, if agency problems reduce a firm's achieved market value, Tobin's $q$ ratio fails to capture the full magnitude of growth opportunities. Instead, a measure of the value of growth opportunities should be independent of the actions of the firm's management, and it should reflect the highest potential value of the firm's investment opportunities. To obtain this potential value, the stochastic frontier technique can again be applied to estimate the upper envelope of the market value of firms' assets as a function of the assets' replacement cost and the characteristics of the markets in which firms operate, in particular, GDP growth and market concentration. As noted previously, this highest potential value results from the management decisions of all firms in the industry and, as such, represents best observed practice in the sample.

Note that the efficiency frontier estimates the highest potential value of a firm's assets across all markets in which the firms in the sample operate, while the investment opportunity frontier estimates the highest potential value of a firm's assets across the markets in which the firm operates. In the case of banks, this latter value is often called the charter value, the value of the bank in a competitive auction. The highest 
potential value in the markets in which a bank operates will be less than the highest value across all banking markets.

Studies using the investment opportunity frontier include Hughes, Lang, Moon, and Pagano (1997), Hughes and Moon (2003), Hughes, Mester, and Moon (2001), Hughes, Lang, Mester, Moon, and Pagano (2003), and Hughes and Mester (2013b).

See Hughes and Mester (2013a, 2015) for further discussion of applying stochastic frontier techniques to measure bank performance and a discussion of the literature.

\section{The Data}

We use 2007 data on top-tier, publicly traded U.S. bank holding companies to estimate the efficiency frontier and the investment opportunities frontier. We have market-value data from Compustat on 219 of these holding companies and we estimate the market-value frontiers with this sample. We have data on ownership structure from the Corporate Library for 142 of the 219 holding companies. Balance-sheet and income statement data are obtained from the Y9-C Call Reports filed quarterly with regulators and available on the website of the Federal Reserve Bank of Chicago. Table 1 provides a list of variables and their definitions. Table 2 presents their summary statistics for the full sample and for the larger and smaller halves measured by the value of consolidated assets.

\section{[INSERT TABLE 1 AND TABLE 2 ABOUT HERE]}

\section{Stochastic Frontier Estimation Techniques}

\section{A. Market-Value Inefficiency - the Magnitude of Agency Costs}

The market-value inefficiency ratio measures the shortfall of a bank's market value adjusted for noise from its highest potential market value, as a proportion of the potential value. The simultaneous estimation of potential value (that is, best observed practice) and elimination of the influence of statistical noise (luck) provides a benchmark from which the magnitude of agency costs can be gauged. 
Stochastic frontier estimation is used to fit an upper envelope of market value to replacement cost to answer the question, what is the highest potential market value of a given investment in bank assets? The difference between the envelope value and the achieved market value of a bank's assets is its market-value shortfall, that is, its lost market value. ${ }^{2}$

The highest potential value of a bank's investment in its assets is estimated by fitting an upper envelope of the market value of banks' assets (MVA) to their replacement cost, proxied by their book value net of goodwill (BVA). We fit the frontier relationship,

$$
\mathrm{MVA}_{\mathrm{i}}=\alpha+\beta\left(\mathrm{BVA}_{\mathrm{i}}\right)+\gamma\left(\mathrm{BVA}_{\mathrm{i}}\right)^{2}+\varepsilon_{\mathrm{i}}
$$

with maximum likelihood techniques, where $\varepsilon_{\mathrm{i}}=v_{\mathrm{i}}-\mu_{\mathrm{i}}$ is a composite error term used to distinguish statistical noise, $v_{\mathrm{i}} \sim$ iid $N\left(0, \sigma_{v}{ }^{2}\right)$, from the systematic shortfall, $\mu_{\mathrm{i}}(\geq 0) \sim$ iid $N\left(0, \sigma_{\mu}{ }^{2}\right)$, from bank i's highest potential (frontier) market value. The quadratic specification allows the frontier to be nonlinear. The frontier value, $\mathrm{FMVA}_{\mathrm{i}}$, is defined by the deterministic kernel of the stochastic frontier,

$$
\mathrm{FMVA}_{\mathrm{i}}=\alpha+\beta\left(\mathrm{BVA}_{\mathrm{i}}\right)+\gamma\left(\mathrm{BVA}_{\mathrm{i}}\right)^{2}
$$

while the stochastic frontier, $\mathrm{SFMVA}_{\mathrm{i}}$, comprises the deterministic kernel and the two-sided error term:

$$
\mathrm{SFMVA}_{\mathrm{i}}=\mathrm{FMVA}_{\mathrm{i}}+v_{\mathrm{i}}
$$

The difference between a bank's stochastic frontier market value and the observed market value defines the bank's market-value shortfall, $\mu_{\mathrm{i}}$, which is measured in dollars of lost market value. Formally, a bank's shortfall is defined either by the difference between its potential value on the stochastic frontier and its observed market value or, equivalently, by the difference between its value on the deterministic kernel and its noise-adjusted market value:

$$
\mu_{\mathrm{i}}=\mathrm{SFMVA}_{\mathrm{i}}-\mathrm{MVA}_{\mathrm{i}}=\mathrm{FMVA}_{\mathrm{i}}-\left(\mathrm{MVA}_{\mathrm{i}}-\mathrm{v}_{\mathrm{i}}\right)
$$

where $\mathrm{MVA}_{\mathrm{i}}-v_{\mathrm{i}}$ is the noise-adjusted observed market value of assets.

\footnotetext{
2 The concept of the market-value shortfall measured by stochastic frontier techniques was proposed by Hughes, Lang, Moon, and Pagano (1997) and was used by Hughes, Lang, Mester, and Moon (1999) to study bank consolidation and by Hughes, Mester, and Moon (2001) and Hughes and Mester (2013b) to evaluate bank scale economies measured as an expansion of bank output along the path that maximizes the bank's value. Note, this path is not generally equivalent to the path that minimizes the bank's cost. See Hughes and Mester (2013a, 2015) for further discussion.
} 
The standard Tobin's $q$ ratio is given by:

Tobin's $q$ ratio $=\mathrm{MVA}_{\mathrm{i}} / \mathrm{BVA}_{\mathrm{i}}$.

We can adjust the standard Tobin's $q$ ratio for noise:

noise-adjusted Tobin's $\boldsymbol{q}$ ratio $=\left(\mathrm{MVA}_{\mathrm{i}}-v_{\mathrm{i}}\right) / \mathrm{BVA}_{\mathrm{i}}$

The shortfall, $\mu_{\mathrm{i}}$, cannot be directly measured, so it is estimated as the expectation of $\mu_{\mathrm{i}}$ conditional on $\varepsilon_{\mathrm{i}}$ :

$\operatorname{shortfall}_{\mathrm{i}}=\mathrm{E}\left(\mu_{\mathrm{i}} \mid \varepsilon_{\mathrm{i}}\right)=\mathrm{FMVA}_{\mathrm{i}}-\left(\mathrm{MVA}_{\mathrm{i}}-\mathrm{E}\left(\mathrm{v}_{\mathrm{i}} \mid \varepsilon_{\mathrm{i}}\right)\right)$.

Bauer (1990) and Jondrow, Lovell, Materov, and Schmidt (1982) describe this technique in detail.

We define the market-value inefficiency ratio as the shortfall normalized by the assets' highest potential value. Hence, a bank's shortfall ratio gives its market-value shortfall as a proportion of the highest potential value of its assets:

market-value inefficiency ratio $_{i}=\operatorname{shortfall}_{i} / \mathrm{FMVA}_{\mathrm{i}}=\mathrm{E}\left(\mu_{\mathrm{i}} \mid \varepsilon_{\mathrm{i}}\right) / \mathrm{FMVA}_{\mathrm{i}}$.

Figure 1 illustrates the deterministic kernel of the stochastic frontier in equation (2). It gives the upper envelope of market values for the achieved noise-adjusted market values. In the example illustrated, the particular book-value investment in assets, 100, achieves a noise-adjusted market value of 108. The highest potential value of this investment, shown on the frontier, is 120 . From the definition in (3), the shortfall in market value from its highest potential value is $120-108=12$. Expressing this shortfall as a proportion of its highest potential value, $12 / 120=0.10$, gives the market-value inefficiency ratio, as defined in (5). In contrast, the noise-adjusted Tobin's $q$ ratio, $108 / 100=1.08$, gives no indication of the size of the shortfall of market value from its best-practice potential value.

\section{[INSERT FIGURE 1 ABOUT HERE]}

The market-value inefficiency ratio offers several advantages over the standard Tobin's $q$ ratio as a measure of financial performance. First, it removes the influence of statistical noise (e.g., luck) on performance and measures a firm's systematic failure to achieve its highest potential (frontier) value. This systematically lost market value captures differences among firms in market advantages, as well as differences in managerial consumption of agency goods. Since managers decide in which local markets their firm should operate, market advantages can be considered as components of managerial effectiveness. Thus, the 
stochastic frontier technique provides a conceptually sound measure of managerial and firm performance. Another advantage of the market-value inefficiency ratio is that the frontier technique identifies lost market value rather than achieved market value; hence, it gauges more directly than Tobin's $q$ ratio the magnitude of agency problems in an industry and permits a direct econometric investigation of the factors that contribute to firms' failure to achieve their highest potential market value.

These advantages of the market-value inefficiency measure are illustrated in Panel A of Table 3, which is based on a partition of the sample of 142 banks into thirds by the magnitude of their market-value inefficiency. ${ }^{3}$ Panel A compares the third with the lowest market-value inefficiency (that is, most efficient) to the third with the highest market-value inefficiency (that is, least efficient). On average, banks in the most efficient third are larger than banks in the least efficient third: $\$ 167.0$ billion vs. $\$ 1.8$ billion mean assets and $\$ 16.2$ billion vs. $\$ 2.0$ billion median assets.

By construction, market-value inefficiency differs between the two groups; however, the difference in lost market value as a proportion of best-practice value is striking: 0.126 for the most efficient versus 0.490 for the least efficient. Notably, there is no statistically significant difference in the investment opportunity ratio between banks in the most and least efficient thirds; nevertheless, the most efficient third achieves a higher mean noise-adjusted Tobin's $q$ ratio, 1.090, compared with 1.056 for the least market-value efficient. The managers of these relatively more efficient banks appear to exploit their investment opportunities more effectively.

The most efficient third has significantly lower ownership by officers and directors: 0.085 versus 0.141. And the most efficient third holds proportionately significantly more financial capital as a proportion of consolidated assets: 0.12 versus 0.10 .

\section{[INSERT TABLE 3 ABOUT HERE]}

\section{B. Value of Investment Opportunities}

Several studies that have used Tobin's $q$ ratio to gauge the value of investment opportunities are reviewed in Section I. When agency problems reduce a firm's achieved market value, Tobin's $q$ ratio will

\footnotetext{
${ }^{3}$ Recall that the frontiers are estimated over the full sample of 219 banks, while the summary statistics are reported for the subsample of 142 banks with data on ownership structure.
} 
underestimate the value of the investment opportunities. This value should reflect best industry practices the highest potential value observed among firms in the industry with similar opportunities and similar bookvalue investments. Thus, while the stochastic frontier defined in equation (1) gives the highest potential value of assets observed over all markets in which banks in the sample operate, the value of investment opportunities limits the calculation to markets in which an individual bank operates. It answers the question, what is the highest potential value of the bank in the markets in which it operates?

To obtain this potential value, we amend equation (1) by adding variables that characterize the economic opportunities of the markets in which a bank operates. Accordingly, we fit a stochastic frontier to banks' market values, where each bank's peers are defined by the book-value investment in its assets $\left(\mathrm{BVA}_{\mathrm{i}}\right)$, the weighted average GDP growth rate $\left(\right.$ Growth $\left._{\mathrm{i}}\right)$ in the markets in which it operates and the weighted average Herfindahl index of market concentration (Herf $\mathrm{i}$ ) for these markets, where the weights are deposit shares. To allow for flexibility, we add the squared value of $\mathrm{BVA}_{\mathrm{i}}$. We interact both growth and market concentration with the investment in assets. Thus, banks' market values are fitted as an upper envelope using maximum likelihood estimation:

$$
\begin{gathered}
\mathrm{MVA}_{\mathrm{i}}=\alpha+\beta_{\mathrm{A}}\left(\mathrm{BVA}_{\mathrm{i}}\right)+\gamma_{\mathrm{AA}}\left(\mathrm{BVA}_{\mathrm{i}}^{2}\right)+\gamma_{\mathrm{AG}}\left(\mathrm{BVA}_{\mathrm{i}}\right)\left(\mathrm{Growth}_{\mathrm{i}}\right) \\
+\gamma_{\mathrm{AH}}\left(\mathrm{BVA}_{\mathrm{i}}\right)\left(\mathrm{Herf}_{\mathrm{i}}\right)+\varepsilon_{\mathrm{i}}
\end{gathered}
$$

where $\varepsilon_{i}=v_{i}-\mu_{i}$ is an error term comprising statistical noise, $v_{i} \sim$ iid $N\left(0, \sigma_{v}{ }^{2}\right)$, and the systematic shortfall, $\mu_{\mathrm{i}}$, where we assume the shortfall is half-normal, $\mu_{\mathrm{i}}(\geq 0) \sim$ iid $N\left(0, \sigma_{\mu}^{2}\right)$. We set $\alpha=0$ to improve the fit of the frontier for small values of assets, which implies that a zero book value of assets is associated with a zero market value of assets (and, in effect, a lack of a charter to operate).

The best-practice value of a firm's investment opportunities in the markets in which it operates is given by this narrowly defined frontier value, $\mathrm{NFVA}_{i}$, obtained from the deterministic kernel of the stochastic frontier:

$$
\begin{aligned}
\mathrm{NFVA}_{i}=\alpha+ & \beta_{\mathrm{A}}\left(\mathrm{BVA}_{\mathrm{i}}\right)+\gamma_{\mathrm{AA}}\left(\mathrm{BVA}_{\mathrm{i}}\right)^{2}+\gamma_{\mathrm{AG}}\left(\mathrm{BVA}_{\mathrm{i}}\right)\left(\mathrm{Growth}_{\mathrm{i}}\right) \\
& +\gamma_{\mathrm{AH}}\left(\mathrm{BVA}_{\mathrm{i}}\right)\left(\mathrm{Herf}_{\mathrm{i}}\right) .
\end{aligned}
$$


This best-practice value of a bank, narrowly defined by the markets in which it operates, represents its charter value, the value of its charter in a competitive auction. Franchise value, the achieved market value, differs from charter value when agency problems erode market value.

To compare the value of investment opportunities of banks differing in asset size, we normalize the frontier value obtained in (7) by the book-value investment in assets adjusted to remove goodwill, which we define as the investment opportunity ratio:

investment opportunity ratio ${ }_{i}=\mathrm{NFVA}_{\mathrm{i}} / \mathrm{BVA}_{\mathrm{i}}$

The estimation of the stochastic frontier in equation (1) yields for a given book-value investment in assets the best-practice market value defined over all banking markets, while the estimation of the frontier in (6) yields the best-practice value defined over the markets in which a bank operates - its charter value. Thus, for any given book-value investment in assets net of goodwill, the franchise value (market value) should generally be less than the charter value, which in turn should be less than the best-practice value defined over all banking markets when a bank's local markets are not all the most valuable. This ordering is confirmed in Table 4, which reports summary statistics for consolidated assets measured in various ways to compare book value with market value and best-practice value in a bank's own market (charter value) with best-practice value over all markets represented in the sample. The mean and median book values of consolidated assets are $\$ 57.4$ (\$4.1) billion and, subtracting goodwill, \$55.6 (\$3.9) billion. Mean and median market (franchise) values, $\$ 59.1$ ( $\$ 4.2$ ) billion, are less than, respectively, the mean and median (stochastic) charter values (the highest potential value in banks' own markets from the stochastic frontier), $\$ 59.3$ (\$4.4) billion, which are in turn less than the mean and median highest potential values over all markets, $\$ 62.1$ (\$6.1) billion, derived from the stochastic frontier.

\section{[INSERT TABLE 4 ABOUT HERE]}

The estimation of the best-practice value of a bank's investment in the markets in which it operates provides a convenient measure of the value of its investment opportunities, which, unlike Tobin's $q$ ratio, is independent of the performance of any individual bank. Panel B of Table 3 illustrates the investment opportunity ratio by providing some summary statistics for the thirds of the sample with the most and least 
valuable investment opportunities. The mean investment opportunity ratio of the least valuable third is 1.067 compared to 1.144 of the most valuable third. Notably, the third with the most valuable investment opportunities achieves a Tobin's $q$ ratio that is not statistically different from that of the third with the least valuable investment opportunities. Thus, the managers in the third with the poorest investment opportunities achieve essentially the same Tobin's $q$ ratio as managers with the most valuable opportunities. As a result, banks in the least valuable third achieve a higher proportion of their best-practice value. The market-value inefficiency of these banks is 0.285 , while the inefficiency of the banks with the most valuable opportunities is 0.345 . Banks holding the least valuable opportunities are on average larger: $\$ 130.8$ billion (median $\$ 5.4$ billion) versus $\$ 10.5$ billion (median $\$ 3.1$ billion).

\section{Some Additional Comparisons}

The comparison in Table 3, Panel A of the sample partitioned into the thirds with the lowest and highest market-value inefficiency showed that the most efficient banks - those operating relatively close to the best-practice frontier - hold more assets and achieve a higher Tobin's $q$ ratio than the least efficient. Their higher market-value efficiency implies they experience relatively lower agency costs than the most inefficient banks, which, not surprisingly, achieve a lower Tobin's $q$ ratio. In addition, officers and directors at banks in the most efficient third own a smaller proportion of outstanding shares.

The comparison of means between the most and least efficient thirds suggests that size may be an important component of efficiency. Table 2 reports that larger banks achieve a higher Tobin's $q$ ratio and a higher proportion of their best-practice market value - that is, they have relatively lower agency costs.

Table 3, Panel C compares means of the lowest and highest thirds of the sample partitioned by the proportion of the outstanding shares owned by officers and directors. The third with the lowest insider ownership is larger and characterized by less valuable investment opportunities. Nevertheless, this third operates closer to the best-practice market-value frontier - that is, with proportionately lower agency costs compared to the third with the highest insider ownership. And the third with the lowest insider ownership achieves a higher Tobin's $q$ ratio. In addition, the third with the lowest insider ownership operates with a 
higher proportion of nonperforming assets, a higher financial capital ratio, and higher ownership by blockholders.

\section{Financial Performance and Agency Costs}

The univariate comparisons suggest relationships of financial performance to such characteristics as asset size, ownership structure, and the value of investment opportunities. We explore these relationships in three regressions differing in the dependent variable measuring financial performance: the market-value inefficiency ratio, Tobin's $q$ ratio, and the noise-adjusted Tobin's $q$ ratio. While Tobin's $q$ ratio measures achieved financial performance and is thus correlated with agency costs, the market-value inefficiency measure more directly gauges agency costs as the difference between best-practice performance and noiseadjusted achieved performance.

\section{A. The Performance Equations}

We apply the general-to-specific modeling strategy to identify the best specification for the market inefficiency ratio equation. ${ }^{4}$ We start with the most general specification for the market inefficiency ratio, which includes all explanatory variables related to theoretical propositions (such as entrenchment, Hicks's (1935) quiet life hypothesis, among many others) made in the existing literature in a way to be fully flexible up to second-order own and cross terms. The root explanatory variables we consider are $\ln$ (book value of assets); a measure of asset quality: the ratio of bad assets to total assets; the investment opportunity ratio; the proportion of outstanding common shares owned by officers and directors at year-end 2006; the proportion of outstanding shares owned by blockholders, that is, holders of 5 percent or more, at year-end 2006; and the Herfindahl index of market concentration. ${ }^{5}$ These variables are defined in Table 1.

Our initial specification includes a constant term and 20 non-constant terms. Since we focus in part on the effects of insider ownership and market concentration on market-value efficiency, we keep the

\footnotetext{
${ }^{4}$ See Hendry (1983) for the first complete application, and Campos, Ericsson, and Hendry (2005) for an overview of this technique.

${ }^{5}$ We used lagged ownership structure to deal with the endogeneity of contemporaneous ownership. The use of instrumental variables to resolve the endogeneity issue is made impractical by the lack of good instruments that explain ownership but not financial performance.
} 
proportion of insider ownership, the proportion of insider ownership squared, the Herfindahl index, and the Herfindahl index squared in the process of applying the general-to-specific modeling strategy. Hence, excepting these four variables, we remove the explanatory variable associated with the largest $p$-value one by one sequentially until all surviving explanatory variables are significant with two-sided $p$-values less than 0.10 . In computing $p$-values, we use White's heteroscedasticity-consistent standard errors. The following four explanatory variables were removed one by one: the investment opportunity ratio squared, the cross of the Herfindahl index and the investment opportunity ratio, the cross of blockholder ownership and $\ln$ (book value of assets), and the cross of blockholder ownership and the Herfindahl index. The Akaike Information Criteria (AIC) and the Schwartz Information Criteria (SIC) of the final specification are -3.896 and -4.542 , while those of the initial specification are -3.872 and -4.435 , indicating that the final specification is preferred to the initial specification.

In short, the performance equations we estimate are specified as follows:

$$
P_{\mathrm{i}}=\boldsymbol{a}+\mathbf{X} \boldsymbol{\beta}+\varepsilon_{\mathrm{i}}
$$

where $P_{\mathrm{i}}=$ performance, as measured by the market-value inefficiency ratio, Tobin's $q$ ratio, and the noiseadjusted Tobin's $q$ ratio; and

$\mathbf{X}$ is the set of regressors:

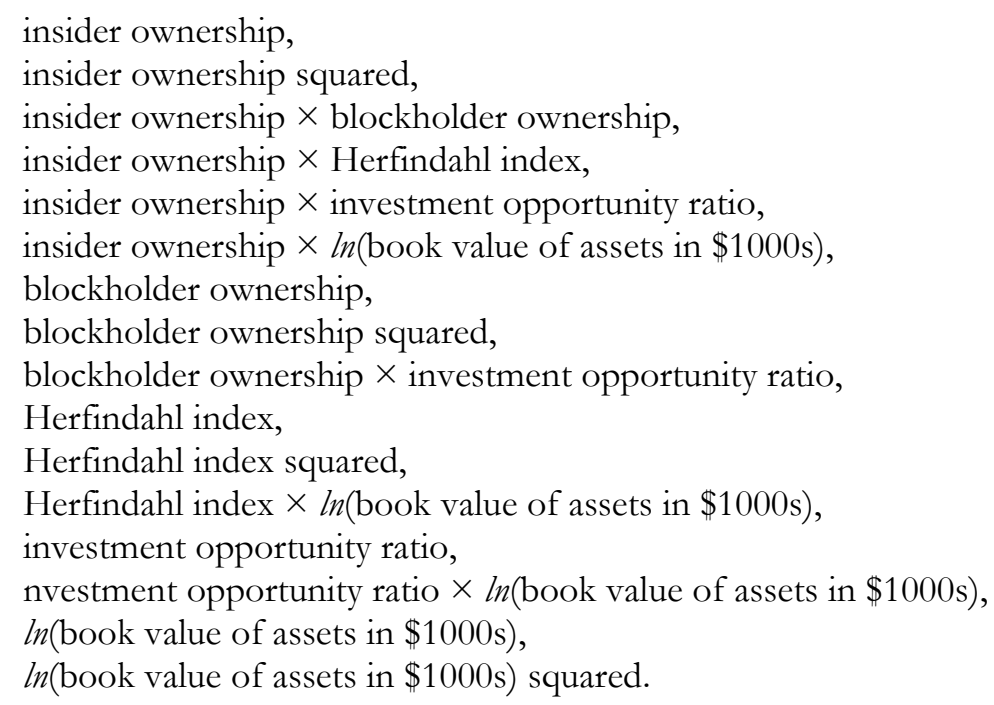




\section{B. Controlling for Asset Size}

The summary statistics in Table 2 highlight some important characteristics of asset size: on average, larger banks are more efficient; insiders own a smaller proportion of large banks; and large banks operate with relatively less valuable investment opportunities. We control for asset size by including $\ln$ (book value of assets) and $\ln$ (book value of assets) squared and we control for asset quality with the ratio of bad assets to

total assets. Bad assets are the sum of past-due and nonaccrual loans, gross charge-offs, and foreclosed real estate. The inclusion of gross charge-offs controls for differences among banks in their aggressiveness in charging off past-due loans. In addition, we interact the $\ln$ (book value of assets) with other variables, which we describe below.

\section{Controlling for Ownership Structure}

Noting that the proportion of outstanding shares owned by an insider represents the insider's price of a dollar of firm value allocated to the insider's private benefit, Jensen and Meckling (1976) contend that higher insider ownership increases the price of agency goods and, thus, better aligns the interests of inside owners with outside owners. The firm managed by an owner of 100 percent of outstanding shares defines the zero-agency-cost case since the agent is the principal. They hypothesize that a firm achieves a higher proportion of its potential value as the manager's ownership stake increases. Using data on small and medium sized firms, Ang, Cole, and Lin (2000) test the Jensen-Meckling hypothesis. They find that firms owned entirely by their top managers achieve higher operating cost efficiency and earn more revenue per dollar of assets than firms partially owned by the top manager or with a hired manager.

In contrast to the alignment-of-interests hypothesis advanced by Jensen and Meckling (1976), Morck, Shleifer, and Vishny (1988) note that as the proportion of the firm owned by insiders increases, it becomes more difficult to fire them or to replace them by a hostile takeover, and they cite Weston (1979), who finds that no firm where insiders own 30 percent or more of outstanding shares had ever been acquired in a hostile takeover. They add to the alignment-of-interests hypothesis a second, contrasting one, the entrenchment hypothesis. As insider ownership increases, managers' interests are better aligned with those of outside owners, so managers tend to consume fewer agency goods; however, managers also become more 
entrenched - more difficult to fire - which implies that they tend to consume more agency goods. They examine U. S. data on nonfinancial firms and estimate a piece-wise linear relationship between performance, measured by Tobin's $q$ ratio, and ownership by officers and directors. For levels of insider ownership between 0 and 5 percent, they find a statistically significant, positive relationship; between 5 and 25 percent, a significant negative relationship; and over 25 percent, weaker evidence of a positive relationship. They conclude that the alignment-of-interests hypothesis dominates entrenchment at less than 5 percent insider ownership and greater than 25 percent, while entrenchment dominates in the 5 to 25 percent range.

DeYoung, Spong, and Sullivan (2001) examine small, closely held U. S. banks in the Tenth Federal Reserve District. Since these banks are small and not actively traded, they lack some of the sources of market discipline found at larger banks. The authors use stochastic frontier methods to estimate a best-practice profit frontier. They find evidence that profit efficiency and insider ownership are positively related at levels of ownership less than 17 percent and negatively related at levels above 17 percent. This turning point is found by regressing profit efficiency on a quadratic specification of insider ownership. The quadratic specification does not allow for a third regime, such as that of Morck, Shleifer, and Vishny (1988). Hughes and Mester (2013a) consider publicly traded U.S. bank holding companies in 1994. Using the market-value inefficiency measure described above, they estimate a cubic relationship between performance and insider ownership and obtain evidence of the three regimes obtained by Morck, Shleifer, and Vishny (1988). They find that at insider ownership less than 15.6 percent, efficiency and ownership are positively related; between 15.6 and 49.7 percent, negatively related; and above 49.7 percent, positively related. Thus, alignment dominates entrenchment at less than 15.6 percent and greater than 49.7 percent. The general pattern of alignment and entrenchment matches that of Morck, Shleifer, and Vishny (1988), but the range of entrenchment, 15.6 to 49.7 , varies considerably from the 5 to 25 percent range.

In each of these investigations, the relationship between performance and a given level of insider ownership is formulated to be independent of the size of the firm. Our specification of the performance equation allows the relationship of performance and any given level of ownership to be influenced by the size 
of the bank, by the proportion of the bank owned by blockholders, by the degree of competition from other banks, and by the value of investment opportunities.

As indicated in Table 2, insiders at smaller banks own, on average, a larger proportion than insiders at larger banks. Insider ownership at large banks is limited by the wealth required to own a large proportion of the institution. Thus, the performance incentive of, say, an ownership stake of 5 percent at a smaller bank may differ from the incentive associated with same 5 percent stake at a larger bank. To allow for this difference, we amend the specification inspired by Morck, Shleifer, and Vishny (1988) by interacting insider ownership with $\ln$ (book value of assets). In this way, the derivative of performance with respect to insider ownership depends not just on the proportion of insider ownership, but also on the $\ln$ (book value of assets) claimed by that ownership stake.

We add the interaction of insider and blockholder ownership to the specification to allow the performance incentive of any given level of insider ownership to vary with the level of ownership by blockholders. Holderness (2003) hypothesizes that monitoring of management by blockholders tends to improve performance, which is a benefit shared by all owners. On the other hand, blockholders can align their interests with those of management and extract private benefits to the detriment of performance. Holderness terms the former the shared-benefits hypothesis and the latter, the private-benefits

\section{hypothesis.}

In addition to the influence of blockholders, we allow the performance incentive of any given level of insider ownership to vary with the degree of competition from other banks by adding the interaction of insider ownership and the Herfindahl index of market concentration. Managers with a large ownership stake may not be able to consume significant amounts of agency goods if their bank operates in highly competitive product markets. Hicks (1935) suggested that the lack of competition in product markets potentially conveyed to managers the benefits of the "quiet life." On the other hand, Petersen and Rajan (1995) hypothesized that banks with market power can price small business loans lower for young businesses to reduce the probability of default and can then make up the subsidy as the business matures and succeeds. Thus, the interaction of market concentration and managerial incentives is likely to be complex. 
Finally, we interact managers' ownership stake with the investment opportunity ratio to allow the performance incentive of any given ownership proportion to vary with the investment opportunities associated with the ownership. Higher-valued opportunities may heighten performance, but entrenched managers who appreciate the consumption of agency goods may reduce their performance as their opportunities increase.

In addition to the interaction of blockholder and insider ownership discussed previously, the influence of blockholders on performance is captured directly by the proportion of outstanding shares owned by blockholders and the proportion squared, which permits a nonmonotonic influence of blockholders. Blockholder ownership is also interacted with the investment opportunity ratio by the same logic as that which supports the interaction with insider ownership.

\section{Controlling for Market Concentration}

Competition in product markets is a commonly cited component of market discipline promoting managerial efficiency. Apropos the lack of this discipline, Hicks (1935) claimed, “The best of all monopoly profits is the quiet life." On the other hand, the previously cited investigation by Petersen and Rajan (1995) found that concentration in lending markets improves the access to credit by informationally opaque borrowers and reduces the default risk of their debt. We allow for the direct, potentially nonmonotonic, influence of concentration by including the Herfindahl index and the index squared in the performance equation. As previously noted, we interact the index with insider ownership. Finally, we interact it with the $\ln$ (book value of assets), which arises from the quadratic specification of the main variables.

\section{E. Controlling for the Value of Investment Opportunities}

In Panel B of Table 3, banks in the third of the sample with the most valuable investment opportunities achieve less of their potential market value than banks in the third with the least valuable opportunities. Consistent with their higher market-value inefficiency, there is no statistically significant difference in Tobin's $q$ ratio between these two groups despite the difference in the value of their investment opportunities. Hughes, Lang, Mester, Moon, and Pagano (2003) note that a higher investment opportunity ratio increases the size of the managers' opportunity set for consuming agency goods as well as for producing 
shareholder wealth. A higher ratio also reduces the probability of financial distress and thereby improves managers' control and their ability to consume agency goods. Thus, the performance equation includes the investment opportunity ratio and its interaction with insider ownership, blockholder ownership, and $\ln$ (book value of assets) as explanatory variables.

\section{F. Estimation Results of the Performance Equations}

Table 5 reports the estimation results of the three performance equations. The overall fit and the precision of the parameter estimates from the equation where performance is measured by the market-value inefficiency ratio are much greater than those when performance is measured by Tobin's $q$ or by the noiseadjusted Tobin's $q$ ratio. Consequently, we investigate only the results from the market-value inefficiency regression.

[INSERT TABLE 5 ABOUT HERE]

\section{G. Performance Incentives of Insider Ownership}

We focus first on the derivative of market-value inefficiency with respect to insider ownership:

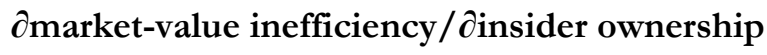

$$
\begin{aligned}
= & -0.85712+(2)(\mathbf{0 . 4 5 0 9 9})(\text { insider ownership }) \\
& +(-\mathbf{0 . 0 7 4 4 1})(\ln (\text { book-value-assets in } \$ 1000 \mathrm{~s})) \\
& +(\mathbf{0 . 4 1 7 6 3})(\text { blockholder ownership })+(\mathbf{1 . 1 5 6 4 9})(\text { Herfindahl index }) \\
& +(\mathbf{1 . 4 8 4 8 4})(\text { investment opportunity ratio). }
\end{aligned}
$$

Values in bold are statistically significant at 10 percent or better. The proportion of lost market value is negatively related to insider ownership through the constant term, which is consistent with the alignment-ofinterests effect, and positively related as insider ownership increases, which is consistent with the entrenchment effect. Thus, an indication of entrenchment - a reversal from a negative to a positive relationship - is likely at higher levels of insider ownership. However, the performance incentive of insider ownership differs between large and small banks. The negative sign of the coefficient on $\ln$ (book value of assets) indicates that at any given level of insider ownership, a larger bank strengthens the alignment-ofinterests performance incentive of ownership. On the other hand, the positive coefficients on the other 
interaction terms suggest incentives consistent with entrenchment. For example, for any given level of insider ownership, an increase in blockholder ownership is associated with higher market-value inefficiency - the private benefits hypothesis of Holderness (2003). And a more concentrated market is associated with increased inefficiency - Hicks's quiet life hypothesis. Finally, a higher investment opportunity ratio, for any given level of insider ownership, is associated with greater inefficiency.

As shown in Table 6, 144 banks have a negative derivative of market-value inefficiency with respect to insider ownership and 28 banks have a positive derivative. Of the 144 banks, 88 have a negative value of the derivative that differs from zero at 10 percent or better. Of the 28 banks, 19 have a positive value that differs from zero at 10 percent or better. Among those banks where the derivatives of inefficiency with respect to insider ownership are statistically different from zero, consistent with a dominance of the alignment-of-interests effect, banks with a negative derivative are larger, have lower insider ownership, operate with relatively less valuable investment opportunities, hold a higher ratio of financial capital, and exhibit a lower market-value inefficiency ratio and a higher Tobin's $q$ ratio. The preponderance of banks with negative-valued derivatives suggests that insider ownership at most banks aligns the interests of inside owners with those of outside owners and improves financial performance.

\section{[INSERT TABLE 6 ABOUT HERE]}

The mean value of the derivative of market-value inefficiency with respect to insider ownership for the significantly negative group of banks, -0.255 , implies that an increase of 1 percent $(+0.01)$ in insider ownership is associated with a 0.255 percent decrease $(-0.00255)$ in market-value inefficiency. In our sample, the most negative value of the derivative, -0.730 , belonging to J. P. Morgan Chase, implies that a 1 percent increase in insider ownership is associated with a 0.730 percent decrease $(-0.00730)$ in market-value inefficiency. This value, which is typical of the largest financial institutions, means that the incentive effects on performance of insider ownership are strongest for the largest banks.

The mean asset size for the statistically significant negative group of banks, $\$ 89.893$ billion, considerably exceeds that of the statistically significant positive group, $\$ 3.926$ billion. For banks labeled systemically important by the Dodd-Frank Wall Street Reform and Consumer Protection Act - those with 
assets exceeding $\$ 50$ billion - all 17 banks exhibit a negative-valued derivative, 16 of which are statistically significantly different from zero.

For the significantly positive group, the mean value of the derivative, 0.196 , implies that a 1 percent increase $(+0.01)$ in insider ownership is associated with an increase of 0.196 percent $(+0.00196)$ in marketvalue inefficiency. The maximum value of this derivative, 0.384 , implies that a 1 percent increase in insider ownership is associated with a 0.384 percent increase in inefficiency. While there is no statistically significant difference in mean blockholder ownership between the two groups, mean insider ownership of the significantly positive group, 0.391 (39.1 percent), exceeds that of the significantly negative group, 0.068 (6.8 percent).

The significantly positive group experiences more valuable investment opportunities. Its mean investment opportunity ratio is 1.124 versus 1.093 of the significantly negative group. In spite of its highervalued investment opportunities and perhaps because of it, the significantly positive group's failure to achieve its potential market value is greater. Its market-value inefficiency is 0.431 (43.1 percent) versus 0.244 (24.2 percent) for the significantly negative group. Tobin's $q$ ratio also reflects this difference in performance. The significantly positive group's mean Tobin's $q$ ratio is 1.051 , while the significantly negative group's ratio is 1.076. The noise-adjusted Tobin's $q$ ratios are 1.044 for the significantly positive group and 1.077 for the significantly negative group. Thus, the banks with a significantly positive derivative of market-value inefficiency with respect to insider ownership show evidence of managerial entrenchment.

\section{H. Performance Incentives of Blockholder Ownership}

Holderness (2003) proposes contrasting influences of blockholders on performance. Monitoring of management by blockholders tends to improve performance, which is a benefit shared by all owners. On the other hand, blockholders can align their interests with those of management and extract private benefits to the detriment of performance. Holderness terms the former the shared-benefits hypothesis and the latter, the private-benefits hypothesis. The derivative of market-value inefficiency with respect to blockholder ownership is given by:

\section{$\partial$ market-value inefficiency/ $\partial$ blockholder ownership}


$=2.01605+(2)(\mathbf{0 . 4 3 3 9 5})($ blockholder ownership $)+(\mathbf{0 . 4 1 7 6 3})$ (insider ownership)

$+(-1.99939)$ (investment opportunity ratio).

Values in bold are statistically significant at 10 percent or better. While all coefficients but one are positive, which suggests support for the private-benefits hypothesis, the negative coefficient of the interaction with the investment opportunity is large and suggests support for the shared-benefits hypothesis. Table 7 reports the evidence obtained from evaluating the derivative (11) for each bank. There are 37 positive values, of which 13 are significantly different from zero. There are 105 negative values, of which 65 are significantly different from zero. Among those banks with significant derivatives, the large number of negative derivatives and the small number of positive values suggests that blockholders provide shared benefits related to monitoring management. Mean blockholder ownership for the significantly positive values is 0.310 (31.0 percent), considerably larger than 0.047 (4.7 percent) for the negative values. The investment opportunity ratio is greater for the negative-valued banks. There is no significant difference in financial performance. There is weak evidence that the banks with negative values are considerably larger.

[INSERT TABLE 7 ABOUT HERE]

\section{Performance Incentives of Market Concentration}

The common textbook hypothesis concerning the performance incentives of product-market concentration points to reduced market discipline of managers, Hicks's quiet life hypothesis. However, the complications of information asymmetries, such as those noted by Petersen and Rajan (1995), suggest that the relationship of performance to concentration may be more complicated. In the specification of this relationship (9), the performance incentive of concentration is given by:

\section{$\partial$ market-value inefficiency/ $\partial$ Herfindahl index}

$$
\begin{aligned}
= & 1.97394+(2)(-2.36996)(\text { Herfindahl index })+(\mathbf{1 . 1 5 6 4 9})(\text { insider ownership }) \\
& +(-\mathbf{0 . 1 0 0 8 5})(\ln (\text { book-value-assets in } \$ 1000 \mathrm{~s})) .
\end{aligned}
$$

Values in bold are statistically significant at 10 percent or better. The coefficient associated with the Herfindahl index in (9) is positive, consistent with the quiet life hypothesis; however, the coefficient of the squared term is negative and implies that the sign of the derivative reverses from positive to negative as 
concentration increases. The positive sign of the coefficient on the interaction with insider ownership suggests that higher levels of insider ownership for any given concentration enhance managerial entrenchment. Finally, larger banks experience better performance for any given level of concentration and insider ownership.

Table 8 shows that the derivative (12) is positive for 112 banks, 66 of which are significantly different from zero, while the derivative is negative for 30 banks, 8 of which are different from zero. There is weak evidence that the banks with negative values are, on average, much larger. Insider ownership is 0.181 (18.1 percent), on average, at banks with positive values, which greatly exceeds the average insider ownership of 0.027 ( 2.7 percent) at the banks with negative values. This might suggest that insider ownership and concentration foster managerial entrenchment; however, market concentration is, on average, greater at banks with negative-valued derivatives. On the other hand, the banks with negative derivatives, on average, operate with relatively lower-valued investment opportunities and with lower market-value inefficiency. The preponderance of positive-valued derivatives suggests that market concentration tends to promote inefficiency and the managerial quiet life.

\section{[INSERT TABLE 8 ABOUT HERE]}

\section{Conclusions}

Stochastic frontier analysis can be used to estimate the best-practice market value of banks in the markets in which they operate - the value of their charter in a competitive auction, which gauges the value of their investment opportunities. In addition, stochastic frontier analysis can estimate banks' best-practice value over all banking markets - their highest potential value. This highest potential value takes into account locational decisions as a factor in determining efficiency. The difference between this potential value and the noise-adjusted achieved value provides an estimate of the systematic lost market value attributable to agency problems as well as operations in less valuable markets. While Tobin's $q$ ratio is often used to measure the value of firms' investment opportunities, it is biased by agency problems within firms. On the other hand, since the stochastic frontiers are estimated from the performance of all firms in the industry, they capture best-practice performance that is independent of the managerial decisions of any particular firm. 
Using these measures of performance applied to 2007 data on top-tier, publicly traded U. S. bank holding companies, we obtain evidence on market discipline. We find that higher managerial ownership and higher blockholder ownership at most banks are associated with improved financial performance. In addition, at most banks, higher product-market concentration is associated with poorer financial performance and the managerial quiet life. Using our measure of investment opportunities, we find evidence that banks with relatively higher-valued investment opportunities achieve less of their potential market value compared to banks with lower-valued opportunities. Despite their lower-valued opportunities, these banks, on average, achieve the same Tobin's $q$ ratio and, thus, appear better able to exploit their less valuable investment opportunities. Our results suggest that higher-valued opportunities may reduce managers' performance pressure and provide a stronger incentive to consume agency goods. 


\section{Bibliography}

Ang, J.S., R.A. Cole and J.W. Lin (2000), 'Agency costs and ownership structure’, Journal of Finance, 55, 81-106.

Baele, L., O. DeJonghe and R. Vander Vennet (2007), 'Does the stock market value bank diversification?' Journal of Banking and Finance, 31, 1999-2023.

Bauer, Paul W. (1990), 'Recent developments in the econometric estimation of frontiers', Journal of Econometrics, 46, 39-56.

Berger, A.N. and T. H. Hannan (1998), 'The efficiency cost of market power in the banking industry: a test of the 'quiet life' and related hypotheses', The Review of Economics and Statistics, 80, 454-465.

Brook, Y., R. Hendershott. and D. Lee (1998), 'The gains from takeover deregulation: evidence from the end of interstate banking restrictions', Journal of Finance, 53, 2185-2204.

Campos, J., N.R. Ericsson, and D.F. Hendry (2005), 'General-to-specific modeling: an overview and selected bibliography', Introduction in J. Campos, N.R. Ericsson, and David F. Hendry (eds.), General-to-Specific Modeling, Edward Elgar Publishing, Cheltenham, 2005.

Core, J.E., R.W. Holthausen and D.F. Larcker (1999), 'Corporate governance, chief executive officer compensation, and firm performance', Journal of Financial Economics, 51, 371-406.

DeJonghe, O. and R. Vander Vennet (2005), 'Competition versus agency costs: an analysis of charter values in European banking,' Working Paper, Ghent University.

DeYoung, R., K. Spong and R.J. Sullivan (2001), 'Who's minding the store? Motivating and monitoring hired managers at small, closely held commercial banks', Journal of Banking and Finance, 25, 1209-43.

Habib, M.A. and A. Ljungqvist (2005), 'Firm value and managerial incentives: a stochastic frontier approach', Journal of Business, 78, 2053-93.

Hendry, D.F. (1983), 'Econometric modelling: the 'consumption function' in retrospect', Scottish Journal of Political Economy, 30, 193-220.

Hicks, John R. (1935), 'Annual survey of economic theory: the theory of monopoly', Econometrica, 8, 1-20.

Holderness, C.G. (2003), 'A survey of blockholders and corporate control', Federal Reserve Bank of New York, Economic Policy Review, 9, 51-64.

Hughes, J.P., J. Jagtiani and L.J. Mester (2016), 'Is bigger necessarily better in community banking?' Federal Reserve Bank of Philadelphia Working Paper.

Hughes, J.P., W. Lang, L.J. Mester and C.-G. Moon (1999), 'The dollars and sense of bank consolidation', Journal of Banking and Finance, 23, 291-324.

Hughes, J.P., W. Lang, L.J. Mester, C.-G. Moon and M. Pagano (2003), 'Do bankers sacrifice value to build empires? Managerial incentives, industry consolidation, and financial performance’, Journal of Banking and Finance, 27, 417-47. 
Hughes, J.P., W. Lang, C.-G. Moon and M. Pagano (1997), 'Measuring the efficiency of capital allocation in commercial banking', Working Paper 98-2, Federal Reserve Bank of Philadelphia (revised as Working Paper 2004-1, Rutgers University Economics Department).

Hughes, J.P. and L.J. Mester (2013a), 'A primer on market discipline and governance of financial institutions for those in a state of shocked disbelief,' Chapter 2 in F. Pasiouras (ed.), Efficiency and Productivity Growth: Modelling in the Financial Services Industry, John Wiley and Sons: West Sussex, U.K., pp. 19-47.

Hughes, J.P. and L.J. Mester (2013b), 'Who said large banks don’t experience scale economies? Evidence from a risk-return-driven cost function', Journal of Financial Intermediation, 22, 559-85.

Hughes, J.P. and L.J. Mester (2015), 'Measuring the performance of banks: theory, practice, evidence, and some policy implications', in Allen N. Berger, Philip Molyneux, and John Wilson (eds.), The Oxford Handbook of Banking, second edition, Oxford University Press, 247-70.

Hughes, J.P., L.J. Mester and C.-G. Moon (2001), 'Are scale economies in banking elusive or illusive? Evidence obtained by incorporating capital structure and risk-taking into models of bank production', Journal of Banking and Finance, 25, 2169-208.

Hughes, J.P. and C.-G. Moon (2003), 'Estimating managers' utility-maximizing demand for agency goods', Working Paper 2003-24, Department of Economics, Rutgers University.

Jensen, M.C. and W.H. Meckling (1976), 'Theory of the firm: managerial behavior, agency costs, and ownership structure', Journal of Financial Economics, 5, 305-360.

Jondrow, J., Lovell, C.A.K., I.S. Materov, and P. Schmidt (1982), 'On the estimation of technical efficiency in the stochastic frontier production function model', Journal of Econometrics, 19, 233-238.

McConnell, J.J. and H. Servaes (1995), 'Equity ownership and the two faces of debt', Journal of Financial Economics, 39, 131-57.

Morck, R., R.M. Shleifer and R.W. Vishny (1988), 'Management ownership and market valuation: an empirical analysis', Joumal of Financial Economics, 20, 293-316.

Petersen, M.A. and Rajan, R.G. (1995), 'The effect of credit market competition on lending relationships', Quarterly Journal of Economics, 110, 407-43.

Weston, J.F. (1979), 'The tender takeover', Mergers and Acquisitions, 74-82.

Yermack, D. (1996), 'Higher market valuation of companies with a small board of directors', Journal of Financial Economics, 40, 185-211.

Yermack, D. (2006), 'Flights of fancy: corporate jets, CEO perquisites, and inferior shareholder returns', Journal of Financial Economics, 80, 211-42. 
Figure 1

\section{Market-Value Frontier}

Stochastic frontier estimation of the relationship of the market value of assets as a quadratic frontier of the book value of assets net of goodwill gives the potential-value frontier as the deterministic kernel of the estimated quadratic function. The error term, $\varepsilon_{\mathrm{i}}=v_{\mathrm{i}}-\mu_{\mathrm{i}}$, is a composite term used to distinguish statistical noise, $v_{i} \sim$ iid $N\left(0, \sigma_{v}{ }^{2}\right)$, from the systematic shortfall from bank i's highest potential (frontier) market value. We adopt the half-normal distribution, $\mu \mathrm{i}(\geq 0) \sim$ iid $\mathrm{N}\left(0, \sigma_{\mu}^{2}\right)$, for this shortfall. The quadratic specification allows the frontier to be nonlinear. In this example, bank i has invested 100 in assets and achieves a market value adjusted for statistical noise, $v_{i}$, of 108 . Its highest potential value is 120 . It fails to achieve $12(=120-$ $108)$ of its potential value. Its market-value inefficiency ratio is $0.10(=12 / 120)$, and its noise-adjusted Tobin's $q$ ratio is $1.08(=108 / 100)$.

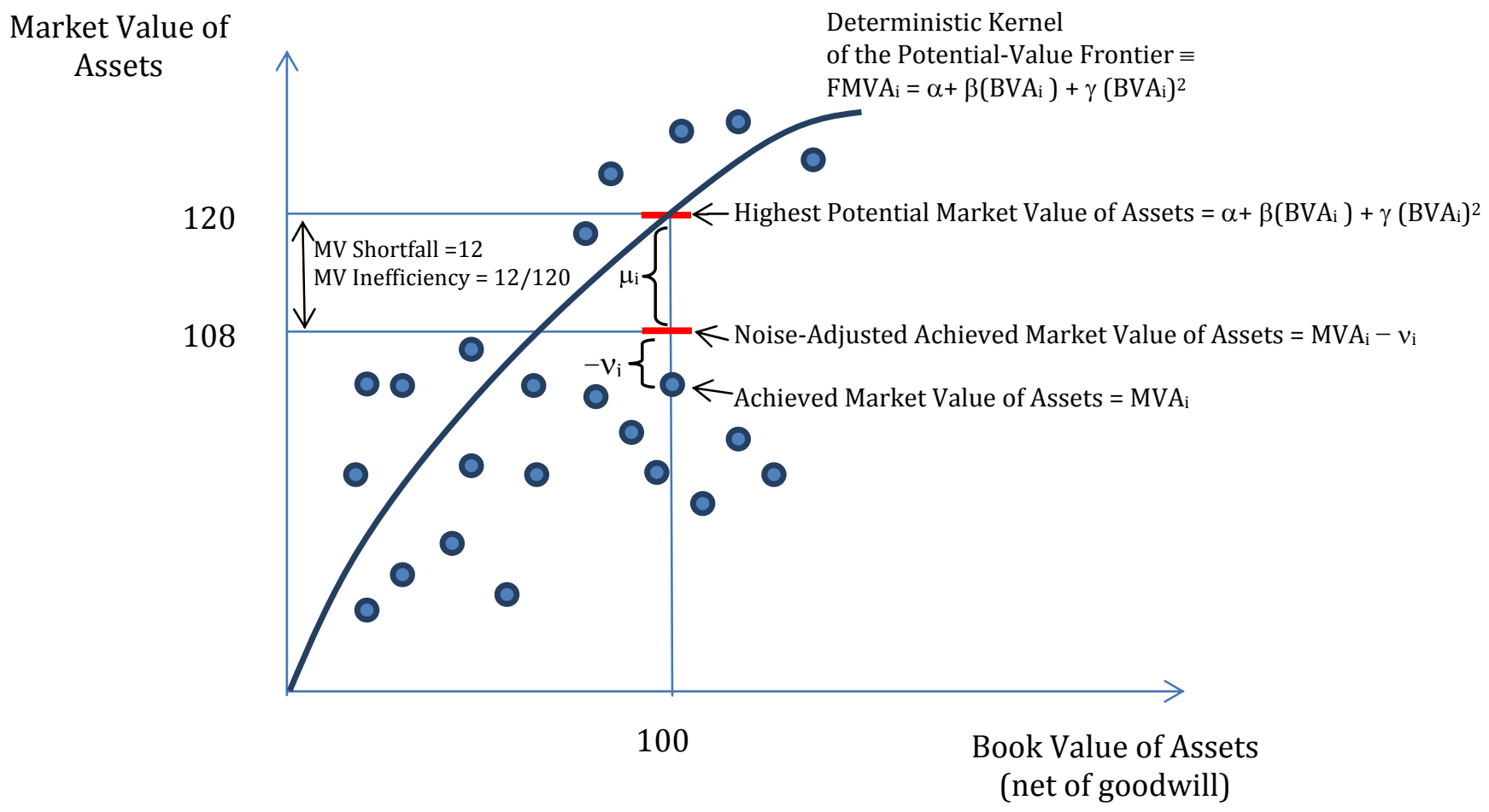

Source: Hughes, Jagtiani, Mester (2016). 


\section{Table 1}

\section{Data Definitions}

Book value of assets represents book value (in thousands of dollars) of total consolidated assets at the end of the 2007. Adjusted book value is obtained by subtracting goodwill from book value to remove components derived from market value. The market value of assets is proxied by the sum of the book value of liabilities and the market value of equity.

The market-value inefficiency ratio is a measure of relative agency costs given by the difference between the highest potential value of a bank's assets over all markets found in the sample and the bank's noise-adjusted achieved market value (lost market value) divided by the highest potential value of assets over all markets, which is estimated by a stochastic frontier technique. The value of a bank's investment opportunities is measured by fitting a stochastic frontier to the market value of assets as a function of the book value of assets and, in the bank's local markets, the marketweighted, 10-year average GDP growth rate and the BHC's market-weighted Herfindahl index of concentration. The investment opportunity ratio is the highest potential value of the bank's assets in the markets in which it operates divided by the book value of assets adjusted to remove goodwill. The weighted Herfindahl index captures the BHC's share of deposits in each state in which it operates where the state deposit share is weighted by the proportion of the bank's total deposits represented by the bank's deposits in the state.

Tobin's $\boldsymbol{q}$ ratio is the ratio of the market value of assets to the adjusted book value of assets. The noise-adjusted Tobin's $\boldsymbol{q}$ ratio is the market value of assets less statistical noise derived from stochastic frontier estimation.

The bad assets ratio is the sum of past-due and nonaccrual loans, gross charge-offs, and foreclosed real estate owned divided by total assets.

The ratio of equity capital to assets is given by the sum of common stock, retained earnings, and perpetual preferred stock divided by total assets. The ratio of financial capital to assets is the sum of equity capital, loan-loss reserves, and subordinated debt divided by total assets.

Insider ownership is the proportion of outstanding shares owned by officers and directors in the year before, that is, in 2006. Blockholder ownership is the percent of outstanding shares held by blockholders (holders of 5 percent or more of outstanding shares based on 13D filings) at year-end 2006. 
Table 2

Summary Statistics for the Full Sample and the Larger and Smaller Halves

The full sample consists of 142 top-tier, publicly traded U. S. bank holding companies at year-end 2007. The data are obtained from the Y9-C Call Reports, Compustat, and the Corporate Library. Definitions of the variables are given in Table 1.

Panel A: Full Sample

\begin{tabular}{|l|c|c|c|c|c|c|}
\hline & $\boldsymbol{N}$ & Mean & Median & Std. Dev. & Minimum & Maximum \\
\hline $\begin{array}{l}\text { Book Value of } \\
\text { Assets (1000s) }\end{array}$ & 142 & $57,427,092$ & $4,088,173$ & $269,582,515$ & 659,896 & $2,187,631,104$ \\
\hline $\begin{array}{l}\text { Insider Ownership } \\
\text { proportion) }\end{array}$ & 142 & 0.120 & 0.077 & 0.134 & 0.000 & 0.694 \\
\hline $\begin{array}{l}\text { Blockholder } \\
\text { Ownership } \\
\text { (proportion) }\end{array}$ & 142 & 0.098 & 0.078 & 0.102 & 0.000 & 0.725 \\
\hline $\begin{array}{l}\text { Investment } \\
\text { Opportunity Ratio }\end{array}$ & 142 & 1.103 & 1.094 & 0.035 & 1.025 & 1.185 \\
\hline $\begin{array}{l}\text { Bad Assets/ } \\
\text { Total Assets }\end{array}$ & 142 & 0.017 & 0.014 & 0.013 & 0.001 & 0.101 \\
\hline $\begin{array}{l}\text { Financial Capital/ } \\
\text { Total Assets }\end{array}$ & 142 & 0.110 & 0.109 & 0.022 & 0.063 & 0.182 \\
\hline $\begin{array}{l}\text { Equity Capital/ } \\
\text { Total Assets }\end{array}$ & 142 & 0.095 & 0.094 & 0.020 & 0.052 & 0.176 \\
\hline $\begin{array}{l}\text { Market-Value } \\
\text { Inefficiency Ratio }\end{array}$ & 142 & 0.308 & 0.314 & 0.162 & 0.000 & 0.719 \\
\hline $\begin{array}{l}\text { Tobin's } q \text { Ratio } \\
\text { Noise-Adjusted } \\
\text { Tobin's } \text { Ratio }\end{array}$ & 142 & 1.071 & 1.066 & 0.043 & 0.978 & 1.230 \\
\hline $\begin{array}{l}\text { Herfindahl Index of } \\
\text { Market } \\
\text { Concentration }\end{array}$ & 142 & 0.080 & 0.079 & 0.038 & 0.018 & 0.231 \\
\hline
\end{tabular}


Table 2

Panel B: Smaller Half of Sample

Values in bold are statistically different from the corresponding mean in the larger half of the sample at the significance level indicated by the superscript.

\begin{tabular}{|c|c|c|c|c|c|c|}
\hline & $\mathbf{N}$ & Mean & Median & Std. Dev. & Minimum & Maximum \\
\hline $\begin{array}{l}\text { Book Value of } \\
\text { Assets (1000s) }\end{array}$ & 71 & $2,313,041^{b}$ & $2,301,037$ & 817,282 & 659,896 & $3,983,420$ \\
\hline $\begin{array}{l}\text { Insider Ownership } \\
\text { (proportion) }\end{array}$ & 71 & 0.150 a & 0.102 & 0.142 & 0.019 & 0.694 \\
\hline $\begin{array}{l}\text { Blockholder } \\
\text { Ownership } \\
\text { (proportion) }\end{array}$ & 71 & 0.091 & 0.069 & 0.088 & 0.000 & 0.343 \\
\hline $\begin{array}{l}\text { Investment } \\
\text { Opportunity Ratio }\end{array}$ & 71 & 1.106 & 1.097 & 0.036 & 1.032 & 1.185 \\
\hline $\begin{array}{l}\text { Bad Assets/ } \\
\text { Total Assets }\end{array}$ & 71 & 0.019 & 0.014 & 0.017 & 0.003 & 0.101 \\
\hline $\begin{array}{l}\text { Financial Capital/ } \\
\text { Total Assets }\end{array}$ & 71 & $0.102^{\mathrm{c}}$ & 0.100 & 0.019 & 0.063 & 0.146 \\
\hline $\begin{array}{l}\text { Equity Capital/ } \\
\text { Total Assets }\end{array}$ & 71 & 0.092 & 0.091 & 0.018 & 0.056 & 0.135 \\
\hline $\begin{array}{l}\text { Market-Value } \\
\text { Inefficiency Ratio }\end{array}$ & 71 & 0.445 & 0.430 & 0.087 & 0.313 & 0.719 \\
\hline Tobin's $q$ Ratio & 71 & $1.059^{a}$ & 1.060 & 0.037 & 0.978 & 1.167 \\
\hline $\begin{array}{l}\text { Noise-Adjusted } \\
\text { Tobin's q Ratio }\end{array}$ & 71 & $1.052^{\mathrm{a}}$ & 1.053 & 0.032 & 0.983 & 1.148 \\
\hline $\begin{array}{l}\text { Herfindahl Index } \\
\text { of Market } \\
\text { Concentration }\end{array}$ & 71 & $0.077^{\text {a }}$ & 0.079 & 0.036 & 0.018 & 0.205 \\
\hline \multicolumn{7}{|c|}{ Panel C: Larger Half of Sample } \\
\hline & $\mathbf{N}$ & Mean & Median & Std. Dev. & Minimum & Maximum \\
\hline $\begin{array}{l}\text { Book Value of } \\
\text { Assets (1000s) }\end{array}$ & 71 & $112,541,143^{b}$ & $10,472,942$ & $374,466,425$ & $4,192,925$ & $2,187,631,104$ \\
\hline Insider Ownership & 71 & $0.089^{a}$ & 0.058 & 0.119 & 0.000 & 0.694 \\
\hline $\begin{array}{l}\text { Blockholder } \\
\text { Ownership }\end{array}$ & 71 & 0.106 & 0.080 & 0.115 & 0.000 & 0.725 \\
\hline $\begin{array}{l}\text { Investment } \\
\text { Opportunity Ratio }\end{array}$ & 71 & 1.100 & 1.094 & 0.034 & 1.025 & 1.166 \\
\hline $\begin{array}{l}\text { Bad Assets/ } \\
\text { Total Assets }\end{array}$ & 71 & 0.015 & 0.014 & 0.008 & 0.001 & 0.038 \\
\hline $\begin{array}{l}\text { Financial Capital/ } \\
\text { Total Assets }\end{array}$ & 71 & $0.118^{c}$ & 0.114 & 0.023 & 0.073 & 0.182 \\
\hline $\begin{array}{l}\text { Equity Capital/ } \\
\text { Total Assets }\end{array}$ & 71 & 0.097 & 0.096 & 0.021 & 0.052 & 0.176 \\
\hline $\begin{array}{l}\text { Market-Value } \\
\text { Inefficiency Ratio }\end{array}$ & 71 & 0.170 & 0.174 & 0.082 & 0.000 & 0.322 \\
\hline Tobin's q Ratio & 71 & $1.083^{a}$ & 1.077 & 0.045 & 1.001 & 1.230 \\
\hline $\begin{array}{l}\text { Noise-Adjusted } \\
\text { Tobin's q Ratio }\end{array}$ & 71 & $1.086^{\mathrm{a}}$ & 1.084 & 0.039 & 1.009 & 1.200 \\
\hline $\begin{array}{l}\text { Herfindahl Index } \\
\text { of Market } \\
\text { Concentration }\end{array}$ & 71 & $0.084^{a}$ & 0.080 & 0.039 & 0.034 & 0.231 \\
\hline
\end{tabular}

a indicates that a difference in the corresponding means between the two size groups is significant at the 0.01 level.

$\mathrm{b}$ indicates that a difference in the corresponding means between the two size groups is significant at the 0.05 level.

$\mathrm{c}$ indicates that a difference in the corresponding means between the two size groups is significant at the 0.10 level. 
Table 3

\section{Comparison of Means}

Sample Partitioned into Highest and Lowest Thirds

by Financial Performance, Value of Investment Opportunities, and Ownership by Officers and Directors

The full sample consists of 142 top-tier, publicly traded U. S. bank holding companies at year-end 2007. The data are obtained from the Y9-C Call Reports, Compustat, and the Corporate Library. Definitions of the variables are given in Table 1. Pairs of means in bold are statistically different at better than $p=0.10$.

\begin{tabular}{|c|c|c|c|c|c|c|c|c|c|}
\hline & \multicolumn{3}{|c|}{$\begin{array}{c}\text { Panel A } \\
\text { Most and Least Efficient } \\
\text { Thirds of the Sample by the } \\
\text { Market-Value Inefficiency } \\
\text { Ratio }\end{array}$} & \multicolumn{3}{|c|}{$\begin{array}{c}\text { Panel B } \\
\text { Highest and Lowest Valued Thirds } \\
\text { of the Sample } \\
\text { by the Investment Opportunity } \\
\text { Ratio }\end{array}$} & \multicolumn{3}{|c|}{$\begin{array}{c}\text { Panel C } \\
\text { Largest and Smallest Thirds } \\
\text { of the Sample by Proportion } \\
\text { of the Bank Owned } \\
\text { by Officers and Directors }\end{array}$} \\
\hline & $\begin{array}{c}\text { Most } \\
\text { Efficient }\end{array}$ & $\begin{array}{c}\text { Least } \\
\text { Efficient }\end{array}$ & & $\begin{array}{c}\text { Highest } \\
\text { Ratio }\end{array}$ & $\begin{array}{c}\text { Lowest } \\
\text { Ratio }\end{array}$ & & $\begin{array}{c}\text { Largest } \\
\text { Proportion }\end{array}$ & $\begin{array}{c}\text { Smallest } \\
\text { Proportion }\end{array}$ & \\
\hline & $\mathbf{N}=47$ & $\mathbf{N}=47$ & & $\mathbf{N}=47$ & $\mathbf{N}=47$ & & $\mathbf{N}=47$ & $N=47$ & \\
\hline & Mean & Mean & $p$ & Mean & Mean & $p$ & Mean & Mean & $p$ \\
\hline $\begin{array}{l}\text { Book Value of } \\
\text { Assets (1000s) }\end{array}$ & $166,990,364$ & $1,844,900$ & 0.00 & $10,524,826$ & $130,767,178$ & 0.08 & $4,490,423$ & $160,598,037$ & 0.02 \\
\hline $\begin{array}{l}\text { Insider Ownership } \\
\text { (proportion) }\end{array}$ & 0.085 & 0.141 & 0.04 & 0.141 & 0.097 & 0.11 & 0.251 & 0.029 & 0.00 \\
\hline $\begin{array}{l}\text { Blockholder } \\
\text { Ownership } \\
\text { (proportion) }\end{array}$ & 0.105 & 0.080 & 0.28 & 0.112 & 0.084 & 0.19 & 0.079 & 0.121 & 0.08 \\
\hline $\begin{array}{l}\text { Investment } \\
\text { Opportunity Ratio }\end{array}$ & 1.100 & 1.110 & 0.15 & 1.144 & 1.067 & 0.00 & 1.118 & 1.099 & 0.01 \\
\hline $\begin{array}{l}\text { Bad Assets/ } \\
\text { Total Assets }\end{array}$ & 0.015 & 0.020 & 0.13 & 0.014 & 0.020 & 0.02 & 0.015 & 0.020 & 0.05 \\
\hline $\begin{array}{l}\text { Financial Capital/ } \\
\text { Total Assets }\end{array}$ & 0.120 & 0.100 & 0.00 & 0.110 & 0.109 & 0.89 & 0.104 & 0.119 & 0.00 \\
\hline $\begin{array}{l}\text { Equity Capital/ } \\
\text { Total Assets }\end{array}$ & 0.096 & 0.090 & 0.19 & 0.096 & 0.093 & 0.32 & 0.093 & 0.097 & 0.46 \\
\hline $\begin{array}{l}\text { Market-Value } \\
\text { Inefficiency Ratio }\end{array}$ & 0.126 & 0.490 & 0.00 & 0.345 & 0.285 & 0.07 & 0.374 & 0.226 & 0.00 \\
\hline Tobin's $q$ Ratio & 1.090 & 1.056 & 0.00 & 1.075 & 1.068 & 0.46 & 1.065 & 1.073 & 0.31 \\
\hline $\begin{array}{l}\text { Noise-Adjusted } \\
\text { Tobin's q Ratio }\end{array}$ & 1.092 & 1.044 & 0.00 & 1.070 & 1.068 & 0.76 & 1.061 & 1.073 & 0.11 \\
\hline $\begin{array}{l}\text { Herfindahl Index } \\
\text { of Market } \\
\text { Concentration }\end{array}$ & 0.088 & 0.086 & 0.88 & 0.080 & 0.088 & 0.33 & 0.080 & 0.088 & 0.38 \\
\hline
\end{tabular}


Table 4

Summary Statistics for Various Characteristics of Consolidated Assets

The full sample comprises 142 top-tier, publicly traded U. S. bank holding companies at year-end 2007. The data are obtained from the Y9-C Call Reports, Compustat, and the Corporate Library. Consolidated assets are measured in book value and market value. Adjusted book value is obtained by subtracting goodwill from book value to remove components derived from market value. The market value of assets is proxied by the sum of the book value of liabilities and the market value of equity. The highest potential value of assets in banks' own markets as well as the highest potential value in all markets is derived from stochastic frontier estimation.

\begin{tabular}{|l|c|c|c|c|c|c|}
\hline & $\boldsymbol{N}$ & Mean & Median & Std. Dev. & Minimum & Maximum \\
\hline $\begin{array}{l}\text { Book Value of } \\
\text { Assets Less } \\
\text { Goodwill (1000s) }\end{array}$ & 142 & $55,628,145$ & $3,910,804$ & $261,624,083$ & 655,798 & $2,146,427,000$ \\
\hline $\begin{array}{l}\text { Book Value Assets } \\
(1000 \text { s) }\end{array}$ & 142 & $57,427,092$ & $4,088,173$ & $269,582,515$ & 659,896 & $2,187,631,104$ \\
\hline $\begin{array}{l}\text { Market Value of } \\
\text { Assets (1000s) }\end{array}$ & 142 & $59,115,745$ & $4,203,937$ & $274,670,589$ & 684,321 & $2,221,073,465$ \\
\hline $\begin{array}{l}\text { Highest Market } \\
\text { Value in Bank's } \\
\text { Markets from } \\
\text { Stochastic Frontier } \\
(1000 s)\end{array}$ & 142 & $59,274,313$ & $4,361,200$ & $274,670,561$ & 841,524 & $2,221,229,497$ \\
\hline $\begin{array}{l}\text { Highest Market } \\
\text { Value over all } \\
\text { Markets from } \\
\text { Stochastic Frontier } \\
\text { (1000s) }\end{array}$ & 142 & $62,134,962$ & $6,082,929$ & $276,763,105$ & $2,334,974$ & $2,226,549,767$ \\
\hline
\end{tabular}


Table 5

\section{Relationship of Financial Performance to Ownership Structure, Market Concentration, the Value of Investment Opportunities, and Consolidated Assets}

The full sample comprises 142 top-tier, publicly traded U. S. bank holding companies at year-end 2007. Regressions are estimated with OLS, and standard errors are heteroscedasticity consistent. The data are obtained from the Y9-C Call Reports, Compustat, and the Corporate Library. Consolidated assets are measured in book value and market value. Adjusted book value is obtained by subtracting goodwill from book value to remove components derived from market value. The market value of assets is proxied by the sum of the book value of liabilities and the market value of equity. The highest potential value of assets in banks' own markets as well as the highest potential value in all markets is derived from stochastic frontier estimation.

Parameter estimates in bold are significantly different from zero at better than $p=0.10$.

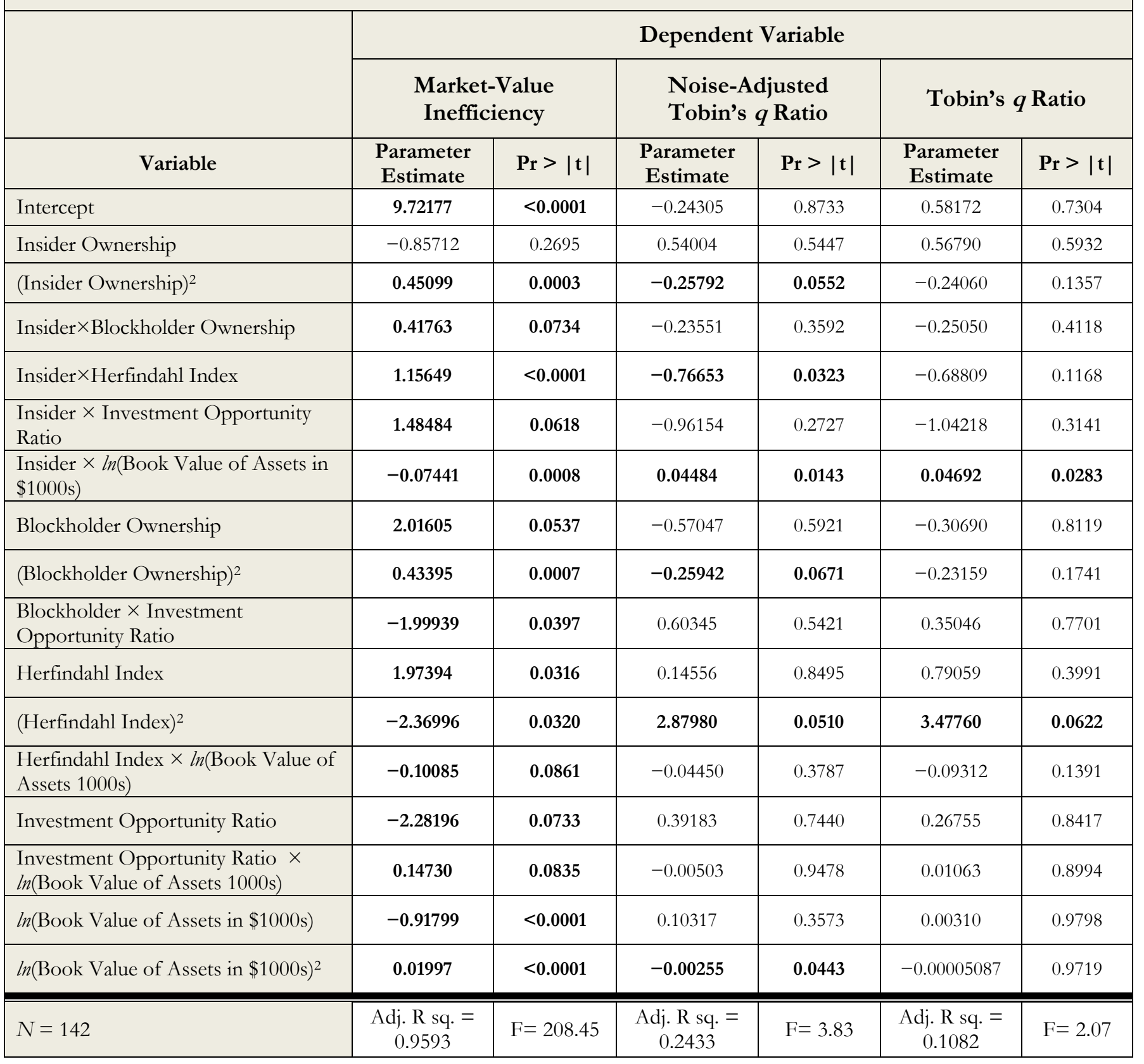


Table 6

\section{The Derivative of Market-Value Inefficiency with Respect to Ownership by Officers and Directors}

The full sample comprises 142 top-tier, publicly traded U. S. bank holding companies at year-end 2007. The data are obtained from the Y9-C Call Reports, Compustat, and the Corporate Library. Consolidated assets are measured in book value and market value. Adjusted book value is obtained by subtracting goodwill from book value to remove components derived from market value. The market value of assets is proxied by the sum of the book value of liabilities and the market value of equity. The highest potential value of assets in banks' own markets as well as the highest potential value in all markets is derived from stochastic frontier estimation. Using the interpretative framework of Morck, Shleifer, and Vishny (1988), a negative value indicates that the alignment-of-interests effect dominates the entrenchment effect, while a positive value implies the dominance of the entrenchment effect. Pairs of means in bold are statistically significantly different at better than $p=0.10$.

\begin{tabular}{|c|c|c|c|c|c|c|}
\hline & \multicolumn{2}{|c|}{ Derivatives of All Banks } & & \multicolumn{2}{|c|}{$\begin{array}{c}\text { Statistically Significant } \\
\text { Derivatives of Banks }\end{array}$} & \\
\hline & $\begin{array}{l}\text { Positive } \\
\text { Valued } \\
N=28\end{array}$ & $\begin{array}{c}\text { Negative } \\
\text { Valued } \\
N=144\end{array}$ & & $\begin{array}{l}\text { Positive } \\
\text { Valued } \\
N=19\end{array}$ & $\begin{array}{c}\text { Negative } \\
\text { Valued } \\
N=88\end{array}$ & \\
\hline & Mean & Mean & $p$ & Mean & Mean & $p$ \\
\hline $\begin{array}{l}\text { Book Value of Assets } \\
(\$ 1000 \mathrm{~s})\end{array}$ & $3,503,142$ & $70,671,571$ & 0.02 & $3,925,556$ & $89,893,463$ & 0.02 \\
\hline $\begin{array}{l}\partial \text { (Market-Value } \\
\text { Inefficiency)/ } \\
\partial \text { (Insider } \\
\text { Ownership) }\end{array}$ & 0.144 & -0.211 & 0.00 & 0.196 & -0.255 & 0.02 \\
\hline $\begin{array}{l}\text { Insider Ownership } \\
\text { (proportion) }\end{array}$ & 0.306 & 0.074 & 0.00 & 0.391 & 0.068 & 0.00 \\
\hline $\begin{array}{l}\text { Blockholder } \\
\text { Ownership } \\
\text { (proportion) }\end{array}$ & 0.091 & 0.100 & 0.68 & 0.086 & 0.085 & 0.97 \\
\hline $\begin{array}{l}\text { Investment } \\
\text { Opportunity Ratio }\end{array}$ & 1.128 & 1.097 & 0.00 & 1.124 & 1.093 & 0.00 \\
\hline $\begin{array}{l}\text { Bad Assets/ } \\
\text { Total Assets }\end{array}$ & 0.019 & 0.017 & 0.56 & 0.017 & 0.017 & 0.97 \\
\hline $\begin{array}{l}\text { Financial Capital/ } \\
\text { Total Assets }\end{array}$ & 0.101 & 0.112 & 0.03 & 0.100 & 0.113 & 0.01 \\
\hline $\begin{array}{l}\text { Equity Capital/ } \\
\text { Total Assets }\end{array}$ & 0.091 & 0.095 & 0.28 & 0.089 & 0.096 & 0.16 \\
\hline $\begin{array}{l}\text { Market-Value } \\
\text { Inefficiency Ratio }\end{array}$ & 0.433 & 0.277 & 0.00 & 0.431 & 0.244 & 0.00 \\
\hline Tobin’s $q$ Ratio & 1.056 & 1.075 & 0.04 & 1.051 & 1.076 & 0.02 \\
\hline $\begin{array}{l}\text { Noise-Adjusted } \\
\text { Tobin's q Ratio }\end{array}$ & 1.049 & 1.074 & 0.00 & 1.044 & 1.077 & 0.00 \\
\hline $\begin{array}{l}\text { Herfindahl } \\
\text { Index of Market } \\
\text { Concentration }\end{array}$ & 0.093 & 0.077 & 0.12 & 0.081 & 0.072 & 0.40 \\
\hline
\end{tabular}




\section{Table 7}

\section{The Derivative of Market-Value Inefficiency with Respect to Ownership by Blockholders}

The full sample comprises 142 top-tier, publicly traded U. S. bank holding companies at year-end 2007. The data are obtained from the Y9-C Call Reports, Compustat, and the Corporate Library. Consolidated assets are measured in book value and market value. Adjusted book value is obtained by subtracting goodwill from book value to remove components derived from market value. The market value of assets is proxied by the sum of the book value of liabilities and the market value of equity. The highest potential value of assets in banks' own markets as well as the highest potential value in all markets is derived from stochastic frontier estimation. Using the interpretative framework of Holderness (2003), a negative value is consistent with the shared-benefits hypothesis, while a positive value is consistent with the private-benefits hypothesis. Pairs of means in bold are statistically significantly different at better than $p=0.10$.

\begin{tabular}{|c|c|c|c|c|c|c|}
\hline & \multicolumn{2}{|c|}{ Derivatives of All Banks } & & \multicolumn{2}{|c|}{$\begin{array}{c}\text { Statistically Significant } \\
\text { Derivatives of Banks }\end{array}$} & \\
\hline & $\begin{array}{c}\text { Positive } \\
\text { Valued } \\
N=37\end{array}$ & $\begin{array}{c}\text { Negative } \\
\text { Valued } \\
N=105\end{array}$ & & $\begin{array}{l}\text { Positive } \\
\text { Valued } \\
N=13 \\
\end{array}$ & $\begin{array}{c}\text { Negative } \\
\text { Valued } \\
N=65\end{array}$ & \\
\hline & Mean & Mean & $p$ & Mean & Mean & $p$ \\
\hline $\begin{array}{l}\text { Book Value of Assets } \\
(1000 \mathrm{~s})\end{array}$ & $11,047,440$ & $73,770,398$ & 0.04 & $12,986,348$ & $55,678,735$ & 0.14 \\
\hline $\begin{array}{l}\partial \text { (Market-Value } \\
\text { Inefficiency)/ } \\
\partial \text { (Blockholder) }\end{array}$ & 0.092 & -0.106 & 0.00 & 0.141 & -0.141 & 0.00 \\
\hline $\begin{array}{l}\text { Insider Ownership } \\
\text { (proportion) }\end{array}$ & 0.192 & 0.094 & 0.01 & 0.114 & 0.102 & 0.63 \\
\hline $\begin{array}{l}\text { Blockholder Ownership } \\
\text { (proportion) }\end{array}$ & 0.186 & 0.068 & 0.00 & 0.310 & 0.047 & 0.00 \\
\hline $\begin{array}{l}\text { Investment } \\
\text { Opportunity Ratio }\end{array}$ & 1.083 & 1.110 & 0.00 & 1.096 & 1.121 & 0.01 \\
\hline $\begin{array}{l}\text { Bad Assets/ } \\
\text { Total Assets }\end{array}$ & 0.018 & 0.017 & 0.84 & 0.012 & 0.016 & 0.13 \\
\hline $\begin{array}{l}\text { Financial Capital/ } \\
\text { Total Assets }\end{array}$ & 0.110 & 0.110 & 0.99 & 0.122 & 0.112 & 0.15 \\
\hline $\begin{array}{l}\text { Equity Capital/ } \\
\text { Total Assets }\end{array}$ & 0.095 & 0.094 & 0.88 & 0.104 & 0.097 & 0.26 \\
\hline $\begin{array}{l}\text { Market-Value } \\
\text { Inefficiency Ratio }\end{array}$ & 0.317 & 0.304 & 0.68 & 0.294 & 0.320 & 0.62 \\
\hline Tobin’s q Ratio & 1.057 & 1.076 & 0.02 & 1.066 & 1.077 & 0.37 \\
\hline $\begin{array}{l}\text { Noise-Adjusted } \\
\text { Tobin's q Ratio }\end{array}$ & 1.059 & 1.073 & 0.06 & 1.068 & 1.072 & 0.75 \\
\hline $\begin{array}{l}\text { Herfindahl } \\
\text { Index of Market } \\
\text { Concentration } \\
\end{array}$ & 0.076 & 0.082 & 0.53 & 0.079 & 0.082 & 0.85 \\
\hline
\end{tabular}




\section{Table 8}

\section{The Derivative of Market-Value Inefficiency}

\section{with Respect to the Herfindahl Index of Market Concentration}

The full sample comprises 142 top-tier, publicly traded U. S. bank holding companies at year-end 2007. The data are obtained from the Y9-C Call Reports, Compustat, and the Corporate Library. Consolidated assets are measured in book value and market value. Adjusted book value is obtained by subtracting goodwill from book value to remove components derived from market value. The market value of assets is proxied by the sum of the book value of liabilities and the market value of equity. The highest potential value of assets in banks' own markets as well as the highest potential value in all markets is derived from stochastic frontier estimation. Pairs of means in bold are statistically significantly different at better than $p=0.10$.

\begin{tabular}{|c|c|c|c|c|c|c|}
\hline & \multicolumn{2}{|c|}{ Derivatives of All Banks } & & \multicolumn{2}{|c|}{$\begin{array}{l}\text { Statistically Significant } \\
\text { Derivatives of Banks }\end{array}$} & \\
\hline & $\begin{array}{c}\text { Positive } \\
\text { Valued } \\
N=112 \\
\end{array}$ & $\begin{array}{c}\text { Negative } \\
\text { Valued } \\
\boldsymbol{N}=30 \\
\end{array}$ & & $\begin{array}{c}\text { Positive } \\
\text { Valued } \\
N=66 \\
\end{array}$ & $\begin{array}{c}\text { Negative } \\
\text { Valued } \\
N=8 \\
\end{array}$ & \\
\hline & Mean & Mean & $p$ & Mean & Mean & $p$ \\
\hline $\begin{array}{l}\text { Book Value of Assets } \\
(1000 \mathrm{~s})\end{array}$ & $4,922,315$ & $253,444,928$ & 0.02 & $3,203,672$ & $372,204,452$ & 0.21 \\
\hline $\begin{array}{l}\partial \text { (Market-Value } \\
\text { Inefficiency)/ } \\
\partial \text { (Herfindahl Index })\end{array}$ & 0.277 & -0.309 & 0.00 & 0.388 & -0.588 & 0.00 \\
\hline $\begin{array}{l}\text { Insider Ownership } \\
\text { (proportion) }\end{array}$ & 0.140 & 0.043 & 0.00 & 0.181 & 0.027 & 0.00 \\
\hline $\begin{array}{l}\text { Blockholder Ownership } \\
\text { (proportion) }\end{array}$ & 0.099 & 0.098 & 0.99 & 0.088 & 0.066 & 0.52 \\
\hline $\begin{array}{l}\text { Investment } \\
\text { Opportunity Ratio }\end{array}$ & 1.106 & 1.091 & 0.03 & 1.108 & 1.077 & 0.02 \\
\hline $\begin{array}{l}\text { Bad Assets/ } \\
\text { Total Assets }\end{array}$ & 0.016 & 0.020 & 0.25 & 0.018 & 0.028 & 0.33 \\
\hline $\begin{array}{l}\text { Financial Capital/ } \\
\text { Total Assets }\end{array}$ & 0.107 & 0.120 & 0.01 & 0.104 & 0.117 & 0.10 \\
\hline $\begin{array}{l}\text { Equity Capital/ } \\
\text { Total Assets }\end{array}$ & 0.095 & 0.092 & 0.49 & 0.094 & 0.089 & 0.54 \\
\hline $\begin{array}{l}\text { Market-Value } \\
\text { Inefficiency Ratio }\end{array}$ & 0.350 & 0.150 & 0.00 & 0.410 & 0.167 & 0.01 \\
\hline Tobin's q Ratio & 1.069 & 1.078 & 0.34 & 1.061 & 1.079 & 0.24 \\
\hline $\begin{array}{l}\text { Noise-Adjusted Tobin's } \\
q \text { Ratio }\end{array}$ & 1.067 & 1.077 & 0.22 & 1.056 & 1.078 & 0.12 \\
\hline $\begin{array}{l}\text { Herfindahl } \\
\text { Index of Market } \\
\text { Concentration }\end{array}$ & 0.071 & 0.117 & 0.00 & 0.064 & 0.174 & 0.00 \\
\hline
\end{tabular}

